\title{
Purification and Proteomic Analysis of Alphavirus Particles from Sindbis Virus Grown in Mammalian and Insect Cells
}

\author{
Raquel Hernandez ${ }^{1, \#, *, ~ T r e v o r ~ G l a r o s ~}{ }^{2, \#}$, Gabrielle Rizzo ${ }^{3}$ and Davis F. Ferreira ${ }^{1,4}$ \\ ${ }^{1}$ Department of Molecular and Structural Biology, North Carolina State University, Raleigh, USA \\ ${ }^{2}$ U.S. Army Combat Capabilities Development Command (CCDC) Chemical Biological Center, Aberdeen Proving \\ Ground, MD 21010, USA \\ ${ }^{3}$ Excet, Inc. 6225 Brandon Ave, Suite 360, Springfield, VA 22150, USA \\ ${ }^{4}$ Institute of Microbiology, Federal University of Rio de Janeiro, Rio de Janeiro, Brazil \\ *For correspondence: Raquel_Hernandez@ncsu.edu \\ \#Contributed equally to this work
}

\section{Abstract}

Current mass spectrometry (MS) methods and new instrumentation now allow for more accurate identification of proteins in low abundance than previous protein fractionation and identification methods. It was of interest if this method could serve to define the virus proteome of a membrane-containing virus. To evaluate the efficacy of mass spec to determine the proteome of medically important viruses, Sindbis virus (SINV), the prototypical alphavirus was chosen for evaluation. This model system was chosen specifically because the alphaviruses contain members which are human pathogens, this virus is well defined biochemically and structurally, and grows to high titers in both vertebrate and non-vertebrate host cells. The SINV proteome was investigated using this method to determine if host proteins are specifically packaged into infectious virions. It was also of interest if the SINV proteome, when grown in multiple host cells representing vertebrate and mosquito hosts, incorporated specific host proteins from all hosts. Observation of recurrent or distinctive proteins in the virus proteome aided in the determination of proteins incorporated into the virion as opposed to those bound to the particle exterior. Mass spectrometry analysis identified the total protein content of purified virions within limits of detection. The most significant finding was that in addition to the host proteins, SINV non-structural protein 2 (nsP2) was detected within virions grown in all host cells examined. This analysis identified host factors not previously associated with alphavirus entry, replication, or egress, identifying at least one host factor integrally involved in alphavirus replication. Key to the success of this analysis is the method of virus purification which must deliver measurably infectious virus free of high levels of contaminants. For SINV and other members of the alphavirus family, this is accomplished by isopycnic centrifugation through potassium tartrate, followed by a high salt wash.

Keywords: Sindbis virus, Mass spectrometry, Virus proteome, Virus purification, Alphavirus, Proteomics

This protocol was validated in: J Virol (2018), DOI: 10.1128/JVI.00694-18 


\section{Background}

The terms proteome and proteomics were coined by Marc Wilkins to describe the systematic evaluation of proteins in a model system using a detailed study of structure, function and regulation of its biology including aberrations which lead to disease (Wilkins et al., 1996 and 2009). However, virus proteomes have been under investigation long before the field of proteomics evolved in an attempt to understand the mechanisms of virus-host interactions in vitro and to evaluate virus pathogenesis of the animal host. To this end it was of interest to evaluate the virus proteome of a model system in a family of viruses which contained medically significant pathogens. Sindbis virus was chosen for this investigation because it is a member of the Alphavirus genus, Family Togaviridae, which contains a significant number of human pathogens of medical importance, it is structurally stable, grows to high titers, is well described in the literature and can be grown in vertebrate and non-vertebrate host cells. Sindbis virus has been the subject of many studies because it is a relatively simple membrane-containing +RNA icosahedral virus (Figure 1). The viral 42S genome is infectious and serves as the template for a 26S subgenomic RNA which encodes the structural genes, organized in the sequence C-PE2(E3/E2)-6K(TF)-E1 3’UTR-polyA (Figure 2). The genomic strand encodes the non-structural proteins in the order 5'UTR-nsP1-nsP2-nsP3-nsP4 (Strauss, J. H. and Strauss, E. G., 1994). The process of virus assembly has marked differences when occurring in vertebrate or invertebrate cells (Brown, 1986). In vertebrate cells the nucleocapsid is pre-assembled in the cytoplasm with the genomic RNA prior to association with the viral protein modified plasma membrane and virus budding from the plasma membrane. In invertebrate cells the virus nucleocapsid and fully matured virus are assembled in endosomes termed "virus factories" prior to fusion of the virus-containing endosomes with the plasma membrane, releasing infectious particles. Depending on the virus' host cells origin, the glycosylation patterns of the glycoproteins will be that specified by the cellular biochemistry and the specific lipid bilayer will be that of the host cell. The virus particles released from either host can be equally infectious and if the SVHR strain of Sindbis virus is used close to $100 \%$ viability is achieved (Vancini et al., 2013). This is an important detail because virus infectivity requires all of its components to be in their metastable conformation and native physical state to be functional that is, infectious (Hernandez et al., 2014). Thus, not all virus particles will be amenable to this method of analysis because the particle structure must be 1) of regular stoichiometry 2) capable of rigorous purification without the loss of infectivity and 3) express a very low particle to PFU ratio. These factors are important to be able to discern any protein contaminants from proteins that are carried within the virus particle. Because of the symmetry of the virus particle and the stoichiometry, the protein concentration can be used to calculate the number of physical particles from the number of infectious particles using the plaque assay to determine infectious particle titer. This specific analysis cannot be applied to nonsymmetrical viruses.

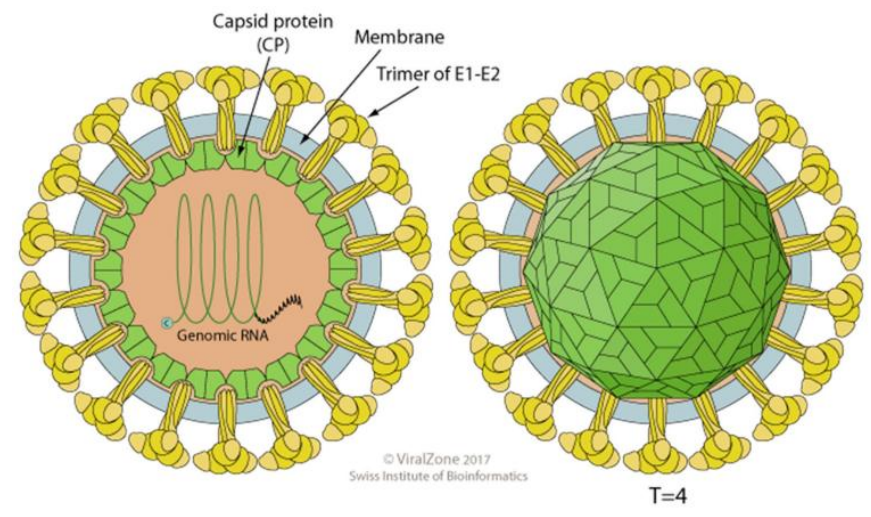

Figure 1. A cartoon of an alphavirus.

The cartoon depicts an enveloped, spherical, icosahedral, $65-70 \mathrm{~nm}$ in diameter, capsid with a $\mathrm{T}=4$ icosahedral symmetry made of 240 monomers 1:1:1 stoichiometric ratio of E1:E2:C. The envelope contains 80 spikes, each spike is a trimer of E1/E2 protein dimers. Reprinted with permission from ViralZone, SBI Swiss Institute of Bioinformatics. Figures from ViralZone, with permission. 


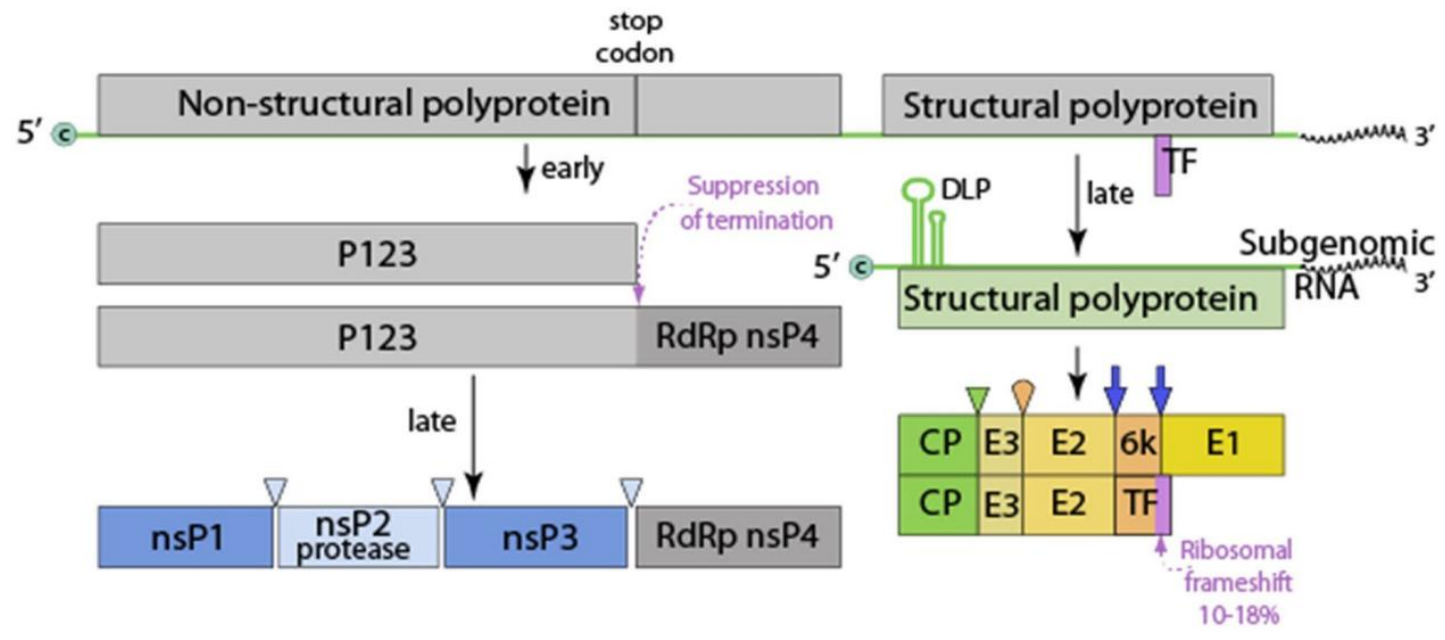

$\nabla$ by $\mathrm{nsP} 2$ protease

$\nabla$ by capsid $\nabla$ by furin $\downarrow$ by signal peptidase

Figure 2. Alphavirus genomic organization.

This genome is monopartite, linear, ssRNA(+) genome of 11-12 kb. The genome is capped (c) and polyadenylated. P123, precursor to nsP1, 2 and 3. Virus proteins are matured by both host and viral proteases. RdRp, RNA dependent RNA polymerase, TF, transframe protein (made from ribosomal frame shift in 6k protein) and DLP (downstream loop), stable RNA structure in the coding sequence of the 5' region of the subgenomic RNA. Figures from ViralZone, with permission.

\section{Stock Virus growth in BHK cells or C7-10 cells}

The heat resistant SINV (SVHR) strain was used in this study. This strain was isolated by Burge and Pfefferkorn in 1966 by collecting virus that was resistant to heating to $54^{\circ} \mathrm{C}$. The choice of virus strain is important because this strain produces high titers $\left(10^{10} \mathrm{PFU} / \mathrm{ml}\right)$ and low particle/PFU ( 1 particle/PFU), ratios of highly infectious and physically stable virus. BHK and C7-10 (Aedes albopictus) cells were obtained from internal collections and are the favored cells to grow SVHR. Virus was harvested from 10 T-75 flasks (Corning) which produces enough virus to form a large visible band in a $30 \mathrm{ml}$ potassium tartrate gradient and sufficient material for the mass spec analysis. Cells were infected at an MOI of $10 \mathrm{PFU} / \mathrm{ml}$, for Sindbis virus infections and allowed to replicate for a single cycle and harvested at $18 \mathrm{~h}$ post infection to ensure that no cell lysis took place. A single cycle of SINV growth from mammalian cells is $\sim 12 \mathrm{~h}$ and from C7-10 cells is about $24 \mathrm{~h}$. The supernatants were clarified by low speed centrifugation (Sorvall RC-5B Super speed centrifuge at 2,000 rpm, $700 \times g$ ). Twenty microliter of the resulting virus supernatant was loaded onto a 15-35\% linear potassium tartrate gradient and twice purified by isopycnic ultracentrifugation (Beckman SW-28 rotor, $18 \mathrm{~h}$ at 10,000 $\times \mathrm{g}$ ). The resulting band of purified virus was collected and washed twice by pelleting the virus in $5 \mathrm{ml} 1 \times$ PBS in an SW-40 Beckman-40 rotor at 45,000 rpm $(12,000 \times g)$ for $30 \mathrm{~min}$ and collecting the pellet.

\section{Virus titration by Plaque assay}

The assay of virus titer by plaque formation, "plaque assay" is the most accurate method for measuring of the amount of infectious virus. This assay is used to determine the titer, in plaque-forming units (PFU) per ml, of virus by infecting a standardized monolayer of cells with a known volume of a known dilution of a virus-containing solution. The infection is contained under agarose which only allows diffusion of the virus to adjacent cells. Virus from a single initially infected cell infects adjacent cells producing a "plaque” or clearing (formed by lysed cells) localized to the original site of infection by an overlay of 1\% agarose in 1× EMEM. Plaques of SVHR are visible to the naked eye after neutral red staining within 2-3 days of incubation at $37^{\circ} \mathrm{C}$. Begin with an estimate of what the titer could be, if the titer is estimated to be around $10^{8} \mathrm{PFU} / \mathrm{ml}$, a flask infected with a dilution of $10^{-6}$ would show 20-200 plaques; in this case, infecting flasks with dilutions of $10^{-5}, 10^{-6}$, and $10^{-7} \mathrm{PFU} / \mathrm{ml}$ should give adequate data to make 
a relatively accurate calculation. If the titer of the virus is completely unknown, it may be necessary to infect flasks or plates with a wide range of dilutions $\left(10^{-1}\right.$ to $\left.10^{-8}\right)$. The number and quality of the plaques seen in a given assay can be influenced by a number of factors, including the $\mathrm{pH}$ and/or temperature of media, dilution buffer, agarose overlay, or the condition of the cell monolayer. Due to the sensitivity of this assay, it is important to include both positive and negative controls within each assay. The negative control is a flask that is inoculated with diluent only, and the positive control consists of one dilution of SVHR stock virus of known titer sufficient to give 20 plaques. This number of plaques is significant statistically.

It is important that when going from a high concentration to a low concentration the pipet tip is changed to avoid "carry over" contamination. However, when pipetting from a low concentration to a higher concentration, as is done when the wells are inoculated, a single pipet tip can be used.

\section{Materials and Reagents}

Note: These can be from any supplier that offers Cell Culture grade materials or reagents except where specified. All culture flasks and plates are standard and can be from any supplier except where noted.

All fetal bovine serum (FBS) should be heat inactivated at $56{ }^{\circ} \mathrm{C}$ for $30 \mathrm{~min}$.

\section{A. Sub-culture of vertebrate and invertebrate cells}

Sub-culture of BHK-21 cells

1. 6-well plates

2. Sterile tissue culture supplies (pipets, vented or plug cap flasks and $15 \mathrm{ml}$ conical tubes)

3. Heat-inactivated fetal bovine serum (FBS)

4. Tryptose phosphate broth

5. L-glutamine

6. Gentamicin sulfate

7. $\mathrm{KCl}$

8. $\mathrm{KH}_{2} \mathrm{PO}_{4}$

9. $\mathrm{NaCl}$

10. $\mathrm{Na}_{2} \mathrm{HPO}_{4}$ or $\mathrm{Na}_{2} \mathrm{HPO}_{4} \cdot 7 \mathrm{H}_{2} \mathrm{O}$

11. $\mathrm{CaCl}_{2}$ or $\mathrm{CaCl}_{2} \cdot 2 \mathrm{H}_{2} \mathrm{O}$

12. $\mathrm{MgCl}_{2} \cdot 6 \mathrm{H}_{2} \mathrm{O}$

13. Complete E-MEM, warmed to $37^{\circ} \mathrm{C}$ (Earl's salts minimal essential medium, completed with $10 \%$ heat inactivated fetal bovine serum, FBS)

14. $1 \times$ PBS-D (see Recipes)

15. Trypsin stock, $0.25 \%$, warmed to $37^{\circ} \mathrm{C}$ (see Recipes)

\section{Sub-culture of C7-10 cells}

1. Sterile tissue culture supplies (pipets, vented or plug cap flasks and $15 \mathrm{ml}$ conical tubes)

2. $70 \%$ ethanol

3. $1 \times \mathrm{MEM}$

\section{B. Virus growth and titration}

\section{Stock virus preparation}

1. Serological pipettes $(5 \mathrm{ml}, 10 \mathrm{ml}$ and $25 \mathrm{ml})$

2. FBS (fetal bovine serum)

3. Sterile Tissue culture grade water: for a detailed discussion of purified water and specifications for cell culture and other grades of water see Laboratory Water (The national institutes of health, March, 2013) 
4. Gentamicin sulfate

5. L-glutamine

6. $\mathrm{KCl}$

7. $\mathrm{KH}_{2} \mathrm{PO}_{4}$

8. $\mathrm{NaCl}$

9. $\mathrm{Na}_{2} \mathrm{HPO}_{4}$ or $\mathrm{Na}_{2} \mathrm{HPO}_{4} \cdot 7 \mathrm{H}_{2} \mathrm{O}$

10. $\mathrm{CaCl}_{2}$ or $\mathrm{CaCl}_{2} \cdot 2 \mathrm{H}_{2} \mathrm{O}$

11. $\mathrm{MgCl}_{2} \cdot 6 \mathrm{H}_{2} \mathrm{O}$

12. Neutral red

13. Complete E-MEM, $1 \times$ and $2 \times$ (see Recipes)

14. Gentamicin sulfate, $100 \times$ (mammalian cells only) (see Recipes)

15. L-glutamine $100 \times$ (see Recipes)

16. HEPES (pH 7.2-7.4), $1 \mathrm{M}$ (see Recipes)

17. $2 \%$ Neutral red stock solution (see Recipes)

18. PBS-D $(10 \times)$ (see Recipes)

19. SVHR diluent (see Recipes)

20. Tryptose phosphate broth (TPB) (optional for ATCC cells) (see Recipes)

\section{Virus titration by plaque formation on BHK cells}

\section{BHK cells preparation}

1. Sterile tissue culture supplies (pipets, vented or plug cap flasks and $15 \mathrm{ml}$ conical tubes)

2. Heat-inactivated fetal bovine serum (FBS)

3. Tryptose phosphate broth

4. L-glutamine

5. Gentamicin sulfate

6. Trypsin

7. $\mathrm{KCl}$

8. $\mathrm{KH}_{2} \mathrm{PO}_{4}$

9. $\mathrm{NaCl}$

10. $\mathrm{Na}_{2} \mathrm{HPO}_{4}$ or $\mathrm{Na}_{2} \mathrm{HPO}_{4} \cdot 7 \mathrm{H}_{2} \mathrm{O}$

11. $\mathrm{CaCl}_{2}$

12. $\mathrm{CaCl}_{2} \cdot 2 \mathrm{H}_{2} \mathrm{O}$

13. $\mathrm{KH}_{2} \mathrm{PO}_{4}$

14. $\mathrm{MgCl}_{2} \cdot 6 \mathrm{H}_{2} \mathrm{O}$

15. Complete E-MEM, warmed to $37^{\circ} \mathrm{C}$ (see Recipes)

16. $1 \times$ PBS-D (see Recipes)

17. Trypsin stock, $0.25 \%$, warmed to $37^{\circ} \mathrm{C}$ (see Recipes)

\section{Virus titration by Plaque assay}

1. $2 \%$ Agarose

2. Heat inactivated Fetal Bovine Serum (FBS)

3. $100 \%$ glycerol

4. Heat-inactivated fetal bovine serum (FBS)

5. Tryptose phosphate broth

6. L-glutamine

7. Gentamicin sulfate

8. Trypsin

9. $\mathrm{KCl}$

10. $\mathrm{KH}_{2} \mathrm{PO}_{4}$ 

11. $\mathrm{NaCl}$
12. $\mathrm{Na}_{2} \mathrm{HPO}_{4}$ or $\mathrm{Na}_{2} \mathrm{HPO}_{4} \cdot 7 \mathrm{H}_{2} \mathrm{O}$
13. $\mathrm{CaCl}_{2}$ or $\mathrm{CaCl}_{2} \cdot 2 \mathrm{H}_{2} \mathrm{O}$
14. $\mathrm{KH}_{2} \mathrm{PO}_{4}$
15. Neutral Red
16. Complete E-MEM $2 \times$ (see Recipes)
17. $2 \%$ Neutral Red (see Recipes)
18. SVHR Diluent (see Recipes)
19. $1 \times$ PBS-D (see Recipes)
20. 1 M HEPES (pH 7.4) (see Recipes)

C. Sindbis virus infection of vertebrate and invertebrate cells

\section{Sindbis virus infection of BHK cells}

1. Centrifuge tubes (Corning, $15 \mathrm{ml}$ Fisherbrand, catalog number: 05-539-5)

2. Sindbis virus infection of C7-10 cells

3. $100 \%$ glycerol (sterile)

4. Tissue culture grade water

5. Heat-inactivated fetal bovine serum (FBS)

6. Tryptose phosphate broth

7. L-glutamine

8. Gentamicin sulfate

9. Trypsin

10. $\mathrm{KCl}$

11. $\mathrm{KH}_{2} \mathrm{PO}_{4}$

12. $\mathrm{NaCl}$

13. $\mathrm{Na}_{2} \mathrm{HPO}_{4}$ or $\mathrm{Na}_{2} \mathrm{HPO}_{4} \cdot 7 \mathrm{H}_{2} \mathrm{O}$

14. $\mathrm{CaCl}_{2}$ or $\mathrm{CaCl}_{2} \cdot 2 \mathrm{H}_{2} \mathrm{O}$

15. $\mathrm{KH}_{2} \mathrm{PO}_{4}$

16. $\mathrm{MgCl}_{2} \cdot 6 \mathrm{H}_{2} \mathrm{O}$

17. Tryptose phosphate broth (TPB; Difco)

18. Complete E-MEM (see Recipes)

19. Gentamicin sulfate $100 \times$ (see Recipes)

20. L-glutamine $100 \times$ (see Recipes)

21. 1 M HEPES (see Recipes)

22. TPB-tryptose phosphate broth (see Recipes)

23. PBS-D $(10 \times)$ (see Recipes)

\section{Sindbis virus infection of C7-10 cells}
1. Glycerol
2. Liquid $\mathrm{N}_{2}$
3. Heat-inactivated fetal bovine serum (FBS)
4. Tryptose phosphate broth
5. L-glutamine
6. Gentamicin sulfate
7. Trypsin
8. $\mathrm{KCl}$
9. $\mathrm{KH}_{2} \mathrm{PO}_{4}$
10. $\mathrm{NaCl}$
11. $\mathrm{Na}_{2} \mathrm{HPO}_{4}$ or $\mathrm{Na}_{2} \mathrm{HPO}_{4} \cdot 7 \mathrm{H}_{2} \mathrm{O}$

Cite as: Hernandez R. et al. (2019). Purification and Proteomic Analysis of Alphavirus Particles from Sindbis Virus Grown in Mammalian and Insect Cells. Bio-protocol 9(10): e3239. DOI: 10.21769/BioProtoc.3239. 

12. $\mathrm{CaCl}_{2}$ or $\mathrm{CaCl}_{2} \cdot 2 \mathrm{H}_{2} \mathrm{O}$
13. $\mathrm{KH}_{2} \mathrm{PO}_{4}$
14. $\mathrm{MgCl}_{2} \cdot 6 \mathrm{H}_{2} \mathrm{O}$
15. Completed E-MEM medium (see Recipes)
16. $1 \times$ PBS-D (see Recipes)

\section{Purification of Sindbis virus}

\section{Purification and Concentration by isopycnic centrifugation}

1. Centrifuge tubes (ultra-clear)

2. Small tube clamp

3. Waste beaker

4. $2 \mathrm{ml}$ cryotube

5. $15 \%$ potassium tartrate (dibasic, hemihydrate) in PBS-D (filter sterilize to store and store at $4{ }^{\circ} \mathrm{C}$ )

6. $35 \%$ potassium tartrate in PBS-D (filter sterilize to store and store at $4{ }^{\circ} \mathrm{C}$ )

7. BCA assay (Pierce ${ }^{\mathrm{TM}}$ Rapid Gold BCA Protein Assay Kit) (Thermo Fisher Scientific, catalog number: A53225)

8. $\mathrm{KCl}$

9. $\mathrm{KH}_{2} \mathrm{PO}_{4}$

10. $\mathrm{NaCl}$

11. $\mathrm{Na}_{2} \mathrm{HPO}_{4}$ or $\mathrm{Na}_{2} \mathrm{HPO}_{4} \cdot 7 \mathrm{H}_{2} \mathrm{O}$

12. $\mathrm{CaCl}_{2}$ or $\mathrm{CaCl}_{2} \cdot 2 \mathrm{H}_{2} \mathrm{O}$

13. $\mathrm{KH}_{2} \mathrm{PO}_{4}$

14. $\mathrm{MgCl}_{2} \cdot 6 \mathrm{H}_{2} \mathrm{O}$

15. PBS-D pH 7.4 (see Recipes)

\section{Concentration of virus by Polyethylene glycol (PEG) precipitation}

1. Kimax high strength glass centrifuge tube (Kimax, catalog number: \#Z2514888) (plain $30 \mathrm{ml}$ )

2. Polyallomer centrifuge tubes

3. Polyethylene glycol-8000 (PEG-8000)

4. $15 \%$ potassium tartrate (dibasic, hemihydrate) in PBS-D

5. $35 \%$ potassium tartrate in PBS-D

6. BCA assay (Pierce ${ }^{\mathrm{TM}}$ Rapid Gold BCA Protein Assay Kit) (Thermo Fisher Scientific, catalog number: A53225)

7. $\mathrm{KCl}$

8. $\mathrm{KH}_{2} \mathrm{PO}_{4}$

9. $\mathrm{NaCl}$

10. $\mathrm{Na}_{2} \mathrm{HPO}_{4}$ or $\mathrm{Na}_{2} \mathrm{HPO}_{4} \cdot 7 \mathrm{H}_{2} \mathrm{O}$

11. $\mathrm{CaCl}_{2}$ or $\mathrm{CaCl}_{2} \cdot 2 \mathrm{H}_{2} \mathrm{O}$

12. $\mathrm{KH}_{2} \mathrm{PO}_{4}$

13. $\mathrm{MgCl}_{2} \cdot 6 \mathrm{H}_{2} \mathrm{O}$

14. Tris Buffer, $\mathrm{pH} 7.0$

15. EDTA

16. PBS-D, pH 7.4 (see Recipes)

17. PEG Buffer (see Recipes)

18. $2 \mathrm{M} \mathrm{NaCl}$ (see Recipes)

\section{E. Calculation of particle to PFU ratio}

None 


\section{F. Mass spectrometry and proteomic analysis}

Note: All reagents should be LCV-MS grade.

\section{Protein Extraction and Digestion}

1. Lo-bind Centrifuge tubes (Eppendorf)

2. Spin filter (Millipore-Ultracell YM-30)

3. Pierce C18 spin columns (Thermo Fisher Scientific)

4. Parafilm

5. Pierce BCA Protein Assay Kit (Thermo Fisher Scientific, catalog number: A53225)

6. Mammalian Protein Extraction Reagent (M-PER) supplemented with $50 \mathrm{mM}$ dithiothreitol (Thermo Fisher Scientific, catalog number: 78501)

7. $0.05 \mathrm{M}$ iodoacetamide in UA buffer

8. Trypsin/Lys-C prepared in $100 \mathrm{mM}$ TEAB to $10 \mu \mathrm{g} / \mathrm{ml}$

9. DTT

10. $\mathrm{CaCl}_{2}$

11. $\mathrm{CaCl}_{2} \cdot 2 \mathrm{H}_{2} \mathrm{O}$

12. $\mathrm{KH}_{2} \mathrm{PO}_{4}$

13. $\mathrm{MgCl}_{2} \cdot 6 \mathrm{H}_{2} \mathrm{O}$

14. $\mathrm{NaCl}$

15. Urea

16. Tris- $\mathrm{HCl} \mathrm{pH} 8.5$

17. TEAB (Sigma, catalog number: T7408-100ML)

18. $100 \%$ trifluoroacetic acid

19. IAA powder

20. Sterile $1 \times$ PBS (see Recipes)

21. UA buffer (see Recipes)

22. $100 \mathrm{mM}$ triethylammonium bicarbonate (TEAB) (see Recipes)

23. $0.5 \mathrm{M} \mathrm{NaCl}$ (see Recipes)

24. $10 \%$ trifluoroacetic acid (TFA) (see Recipes)

25. M-PER supplemented with $50 \mathrm{mM}$ dithiothreitol (DTT)

26. Iodoacetamide (IAA) solution (0.05 M IAA in UA buffer) (see Recipes)

27. Trypsin digestion solution (see Recipes)

\section{LC-MS/MS Data Acquisition}

1. Picofrit $15 \mathrm{~cm} \times 75 \mu \mathrm{m}$ ID HPLC column packed with $5 \mu \mathrm{m}$ BioBasic C18 particles $300 \AA$ (New Objective)

2. $3 \%$ acetonitrile $/ 0.1 \%$ formic acid

3. $100 \%$ formic acid (Thermo Scientific, catalog number: 28905)

4. $100 \%$ acetonitrile

5. A Buffer (see Recipes)

6. B Buffer (see Recipes)

\section{Equipment}

\section{A. Sub-culture of vertebrate and invertebrate cells}

1. $25 \mathrm{~cm}^{2}$ flask

2. $75 \mathrm{~cm}^{2}$ flask

3. $\mathrm{CO}_{2}$ Cell culture incubator (Any supplier is adequate)

Note: Any supplier is adequate; the choices are price/quality and capacity. All that is necessary is a water- 
jacketed incubator which can be regulated to $5 \% \mathrm{CO}_{2}$ in a water-saturated atmosphere. This will require a medical grade $\mathrm{CO}_{2}$ tank (liquid gas under pressure) and a pressure regulator specific for that tank. Two incubators will be required if the cells are to be grown simultaneously because the vertebrate cells are incubated at $38{ }^{\circ} \mathrm{C}$ and invertebrate cells at $28^{\circ} \mathrm{C}$.

4. Biological safety cell culture hood

5. Inverted microscope

6. Hemacytometer

\section{B. Virus growth and titration}

Stock virus preparation

1. $\mathrm{CO}_{2}$ Cell culture incubator

Virus titration by Plaque assay

1. Rocker platform (Bellco Biotechnology)

2. $37^{\circ} \mathrm{C}$ water bath

3. Dilution tube rack

4. Ice bucket

\section{Sindbis virus infection of vertebrate and invertebrate cells}

Sindbis virus infection of BHK cells

1. Platform rocker (Bellco Biotechnology)

2. Hemocytometer

Sindbis virus infection of C7-10 cells

1. $75 \mathrm{~cm}^{2}$ flasks

2. Centrifuge

3. Hemocytometer

\section{Purification of Sindbis virus}

\section{Purification and Concentration by isopycnic centrifugation}

1. Inverted microscope

2. Platform rocker (Bellco Biotechnology)

3. Hemocytometer or cell counting device

4. Corning ${ }^{\mathrm{TM}}$ polypropylene tubes (micro centrifuge tubes, self-standing and conical)

5. Sorvall RC-5B Super speed centrifuge

6. Beckman ultracentrifuge

7. Beckman SW-28 rotor

8. Polyallomer $38 \mathrm{ml}$ tubes

9. Beckman SW-55Ti

10. Polyallomer $5 \mathrm{ml}$ tubes

11. Ring stand

12. Small tube clamp

13. Hand held low-intensity lamp 
14. 30-100 ml gradient former (Bio-Rad, model 385)

15. Medium stir plate

Concentration of virus by Polyethylene glycol (PEG) precipitation

1. Sorvall RC-5B Super speed centrifuge

2. Beckman ultracentrifuge and appropriate rotor and tubes for the volume used

3. $\quad 30-100 \mathrm{ml}$ gradient former (Bio-Rad, model 385)

E. Calculation of particle to $\mathrm{PFU}$ ratio

None

\section{F. Mass spectrometry and proteomic analysis}

\section{Protein Extraction and Digestion}

1. Tabletop centrifuge capable of reaching up to $14,000 \times g$

2. Shaker heat block

3. Vortex

4. SpeedVac Concentrator

\section{LC-MS/MS Data Acquisition}

1. Orbitrap ELITE mass spectrometer (or equivalent; e.g., Orbitrap QE+, Orbitrap Fusion, Orbitrap Fusion Lumos)

2. Easy-nLC II liquid chromatography system (or equivalent HPLC/UHPLC nanoflow pump system)

\section{Software}

Data Processing:

1. High performance computer meeting the minimum specifications to run Proteome Discoverer Software (Currently available version: 2.2; Thermo Fisher Scientific)

2. PANTHER classification system (http://www.pantherdb.org/)

\section{Procedure}

\section{Protocol outline:}

A. Sub-culture of vertebrate and invertebrate cells

1. Sub-culture of BHK cells

2. Sub-culture of C7-10 cells

B. Virus growth and titration

1. Preparation of stock virus

2. Virus titration by plaque assay

C. Sindbis virus infection of vertebrate and invertebrate cells

1. Sindbis virus infection of BHK cells

2. Sindbis virus infection of C7-10 cells 
D. Purification of Sindbis virus

1. Concentration by isopycnic centrifugation

2. Concentration by polyethylene glycol (PEG) precipitation

E. Calculation of particle/PFU ratio

F. Mass Spectrometry and Proteomic Analysis

1. Protein Extraction and Digestion

2. LC-MS/MS Data Acquisition

3. Data Processing

\section{A. Sub-culture of vertebrate and invertebrate cells}

\section{Sub-culture of BHK-21 cells}

Individual stocks of BHK cells may require different passage schedules and may have different levels of viable passages. It is good practice to keep track of the number of passages that an individual culture can be subcultured so that a schedule of cell thawing and storage can be established.

Fresh newly thawed cells can be passaged up to 30 times. If you are not going to split them immediately, cells can be incubated at $28{ }^{\circ} \mathrm{C}$ for 2 to 3 days but must be split at least once to recover normal growth before use in experiments.

1. Wash a confluent BHK cell monolayer once with $1 \times$ PBS-D, using $5 \mathrm{ml}$ for a $25 \mathrm{~cm}^{2}$ flask or $15 \mathrm{ml}$ for a $75 \mathrm{~cm}^{2}$ flask.

2. Decant PBS-D and add trypsin to the monolayer. Add $2 \mathrm{ml}$ to a $25 \mathrm{~cm}^{2}$ flasks, or $5 \mathrm{ml}$ to a $75 \mathrm{~cm}^{2}$ flask. Incubate at room temperature until the cells begin to detach from the flask. Disrupt cell clumps by pipetting up and down using a 5 to $10 \mathrm{ml}$ serological pipet.

3. Add BHK cell culture medium to a volume of 1:1 to stop trypsin. Resuspend cells in the trypsin solution and check for cell clumps by under the microscope. If there are significant remaining clumps, pipet up and down using a 5 to $10 \mathrm{ml}$ serological pipet.

4. Pipet cell solution into a conical tube of the appropriate size.

5. Spin tube(s) at $500 \times g$ (medium speed on a tabletop centrifuge) for 3 to $5 \mathrm{~min}$ to form a firm pellet. Do not overfill tube. Do not invert tube to mix.

6. Decant supernatant and replace with the appropriate amount of medium.

a. For preparation of a single 25- $\mathrm{cm}^{2}$ flask: resuspend in $3 \mathrm{ml}$ E-MEM. Add $1 \mathrm{ml}$ of cells to $10 \mathrm{ml}$ of medium in the flask. Up to 3 flasks can be prepared from one initial $25 \mathrm{~cm}^{2}$ flask, at a 1:3 split ratio (area of the flask).

b. For preparation of a large number of $25-\mathrm{cm}^{2}$ flasks (plaque flasks or plates): To a sterile bottle, add $10 \mathrm{ml}$ E-MEM per each flask to be prepared. If you are using 6-well plates use $2 \mathrm{ml} /$ well. Remove some medium from the bottle and resuspend cells. Add back to the rest of the medium and mix well. To prepare multiple flasks or plates aliquot $10 \mathrm{ml}$ of the cell mixture into each flask $25-\mathrm{cm}^{2}$ flasks, swirling continuously. One $75 \mathrm{~cm}^{2}$ flask will make $9-25 \mathrm{~cm}^{2}$ flasks or 4 - 6-well plates are (9.5 $\mathrm{cm}^{2} /$ well $\times 6$ wells $=57 \mathrm{~cm}^{2}$ total) using $2 \mathrm{ml} /$ well.

Note: This protocol ensures that the cell monolayers will be uniform and contain approximately the same number of cells. Care should be taken when placing the flasks into the incubator so as not to disturb the cell suspension.

c. For preparation of a single $75-\mathrm{cm}^{2}$ flask: Aliquot $1 \mathrm{ml}$ of cells from a single $25 \mathrm{~cm}^{2}$ flask into $30 \mathrm{ml}$ complete E-MEM.

7. Incubate cells in flasks at $37^{\circ} \mathrm{C}$ for $24 \mathrm{~h}$ or until confluent.

8. If medium does not hold $\mathrm{pH}$ of $<8$, adjust $\mathrm{pH}$ with $1 \mathrm{M}$ HEPES to a final concentration of $8 \mathrm{mM}$ HEPES. This is normally not necessary however if the $\mathrm{pH}$ needs adjusting then it should be between $\mathrm{pH} 7$ and 8 .

\section{Sub-culture of C7-10 cells}

1. Maintain mosquito cell lines in semi-suspension in tissue culture flasks at $28{ }^{\circ} \mathrm{C}$ in a $5 \% \mathrm{CO}_{2}$ humidified 
environment. Subculture up to every other day as described below. The cells need to be split when they begin to clump or float. These cells like to be concentrated; do not split more than $1 / 3 \times$ the area of the monolayer.

Notes:

a. Semi-suspension cells adhere loosely to the substrate initially, and then begin to float as they age. Some cells may stick tightly to the substrate.

b. Do not attempt to completely disrupt the clumps or scrape the cells, this damages the cells.

2. Clean the area under the hood with $70 \%$ ethanol. Clean all materials going under the hood with $70 \%$ ethanol and remove unneeded materials.

3. Place media at room temperature to warm.

4. Remove cell flasks from the incubator. Observe cell media for changes in color (red) and clarity.

5. Visualize cells under a microscope at $20 \times$ magnification to check monolayer for irregularities, and confluency. Cells need to be $95 \%-100 \%$ confluent prior to passage. Cells will be at a density of $\sim 2 \times 10^{8}$ cells/75 $\mathrm{cm}^{2}$ flask in $25 \mathrm{ml}$ of medium.

6. Hit the side of the flask sharply on any soft surface several times to loosen any cells that are stuck to the surface of the flask.

Notes:

a. If the cells are aggregated into clumps, try to break up the clumps by pipetting up and down several times using a 5-10 ml pipet, before transferring the cells to a new flask.

b. Small clumps are acceptable.

7. Transfer one-third of the $25 \mathrm{ml}$ of the medium of the cell suspension to each of three flasks. To each of these flasks, add fresh media to increase the volume to the original $25 \mathrm{ml}$. Add $25 \mathrm{ml}$ of fresh $1 \times$ MEM to the original flask if there are many adherent cells remaining if the cells are needed. If not, omit this step.

8. Cap flasks tightly if the caps are vented, leave loose for non-vented caps.

9. Return flasks to the incubator set no higher than $26{ }^{\circ} \mathrm{C}$. Mosquito cells will go into heat-shock at temperatures higher than $34^{\circ} \mathrm{C}$.

\section{B. Virus growth and titration}

\section{Stock virus preparation}

It is standard practice to grow a stock of virus from which additional virus stocks will be grown prior to any additional work with the virus. This practice avoids the production of defective interfering particles which will accumulate upon successive serial passage of high concentrations of virus. Generally, an MOI (multiplicity of infection) of $0.01 \mathrm{PFU}$ (plaque forming units) per cell is required for production of stock virus. To calculate the correct MOI, the number of cells to be infected must be known. Then multiply the number of cells by the required MOI, e.g., $10^{6}$ total cells to be infected $\times$ MOI of $0.01=10^{4} \mathrm{PFU}$ of virus inoculum is needed.

If your stock virus is $1 \times 10^{9} \mathrm{PFU} / \mathrm{ml}$ and you need a $10^{4} \mathrm{PFU}$ inoculum, do the following:

1. Make a serial dilution of the stock virus, begin by making a 1:10 dilution of the stock virus to a total of 1 $\mathrm{ml}$. This will be $100 \mu \mathrm{l}$ of virus supernatant in $900 \mu \mathrm{l}$ of PBS-D + 3\% FBS. This is a $10^{-1}$ virus dilution.

2. Make a serial dilution of this sample so that you get -1 through -4 dilutions in 5 separate tubes (see Figure

$3)$. The amount of virus that you need is in the -4 dilution tube, $1 \mathrm{ml}$ of virus of $10^{-4} \mathrm{PFU} / \mathrm{ml}$. 


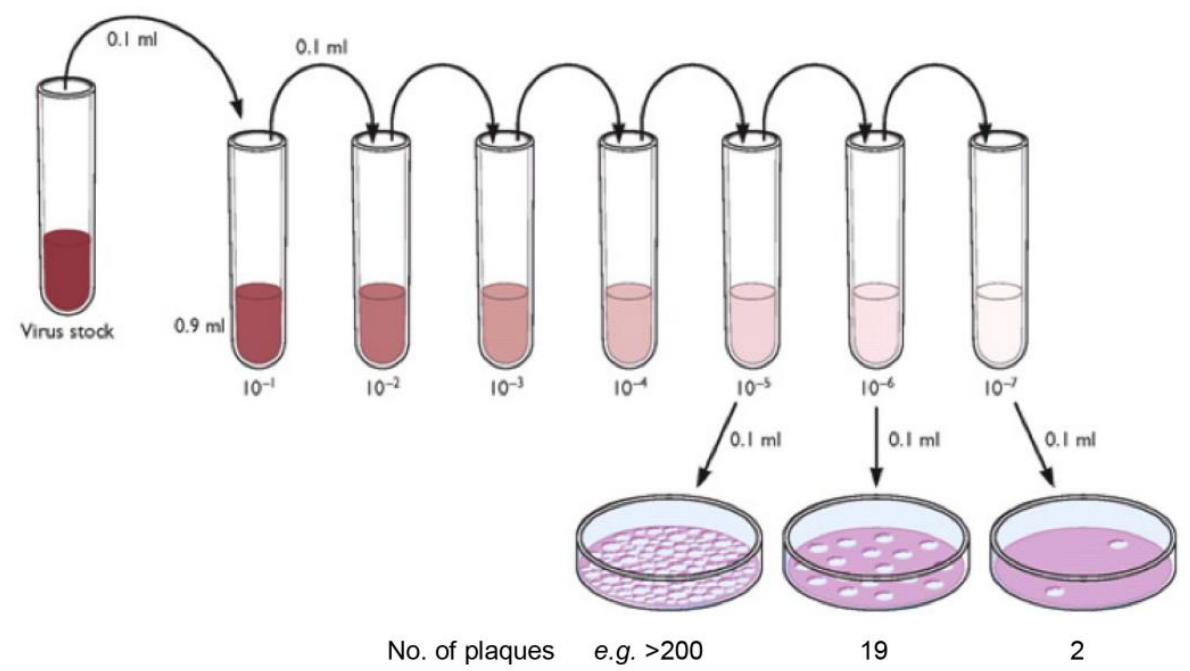

Figure 3. Serial passage scheme.

The figure is modified from http://www.virology.ws/2009/07/06/detecting-viruses-the-plaque-assay/. This work is licensed under a <a rel="license" href="http://creativecommons.org/licenses/by/3.0/">Creative Commons Attribution 3.0 Unported License $</ a>$.

3. Make as much of this dilution as you need to infect all of your flasks with $1 \mathrm{ml} / 75 \mathrm{~cm}^{2}$ flask. Do not be tempted to use an inoculum of less than a $50 \mu \mathrm{l}$ measurement of virus because the only correct way to dilute virus is to make a serial dilution. Virus particles do not go into true solution and care must be taken to suspend them correctly, otherwise the counts will be artificially high or low. Alternatively, you can use $100 \mathrm{\mu l}$ of the -5 dilution up to a volume of $1 \mathrm{ml}$ or use the entire -5 dilution to make $10 \mathrm{ml}$ of the virus and arrive at the correct MOI.

4. Refreeze your initial stock virus; this is your primary stock from which you will grow subsequent stocks. Virus is quantitated by plaque assay on the cells from which the virus produces CPE which is usually the cell line from which it is produced (in this case BHK). However Sindbis virus does not produce CPE in many insect cells (e.g., U4.4 of C7-10 cells), which cannot be used for the plaque assay.

Notes:

a. Stock virus can be grown from vertebrate or invertebrate cells.

b. Sindbis virus is very sticky and will bind to glass and plastic surfaces. We have found that Corning ${ }^{T M}$ polypropylene tubes (microcentrifuge tubes, self-standing and conical) bind fewer virus particles than other brands of plastic. Disposable glass tubes are used to make the virus dilutions required for the plaque assay.

c. Tissue culture grade reagents from all major suppliers have been found suitable for the cell culture and virus production portions of this protocol.

\section{Virus titration by plaque formation on BHK cells}

\section{Preparation of BHK cells}

Note: Individual stocks of BHK cells, e.g., from ATCC, may require different passage schedules and may have different numbers of viable passages.

1. Wash a confluent BHK cell monolayer once with $1 \times$ PBS-D, using $5 \mathrm{ml}$ for a $25 \mathrm{~cm}^{2}$ flask or $15 \mathrm{ml}$ for a $75 \mathrm{~cm}^{2}$ flask.

2. Decant PBS-D and add trypsin to the monolayer. Add $2 \mathrm{ml}$ to a $25 \mathrm{~cm}^{2}$ flasks, or $5 \mathrm{ml}$ to a $75 \mathrm{~cm}^{2}$ flask. Incubate at room temperature until the cells begin to detach from the flask. Disrupt cell clumps by pipetting up and down using a 5 to $10 \mathrm{ml}$ serological pipet. 
3. Add BHK medium 1:1 to stop trypsin. Resuspend cells in the trypsin solution and check for cell clumps by under the microscope. If there are significant remaining clumps, pipet up and down using a 5 to $10 \mathrm{ml}$ serological pipet.

4. Pipet cell solution into a conical tube of the appropriate size, e.g., 10 or $50 \mathrm{ml}$ tubes.

5. Spin tube(s) at $500 \times g$ (medium speed on a tabletop centrifuge) for 3 to 5 min to form a firm pellet. Do not overfill tube. Do not invert tube to mix.

6. Decant supernatant and replace with the appropriate amount of medium $3 \mathrm{ml}$ for $25-\mathrm{cm}^{2}$ flask and $9 \mathrm{ml}$ for a $75 \mathrm{~cm}^{2}$ flask.

a. For preparation of a single $25-\mathrm{cm}^{2}$ flask: Resuspend in $3 \mathrm{ml}$ E-MEM. Add $1 \mathrm{ml}$ of cells to $10 \mathrm{ml}$ of medium in the flask. Up to 3 flasks can be prepared from one initial $25 \mathrm{~cm}^{2}$ flask, at a 1:3 split ratio (area of the flask). Cap flasks tightly (vented caps, leave loose for non-vented caps).

b. $9-25 \mathrm{~cm}^{2}$ flasks can be prepared from $1-75 \mathrm{~cm}^{2}$ flask.

\section{The materials for plaque assay}

Many of the materials used for the plaque assays are used for both mammalian and mosquito cell assays. It is important to make the serial dilutions of virus immediately prior to infection of the plaque assay flasks/plates to limit the amount of virus binding to the tubes.

1. Determine the number of plates/flasks required, with two wells per dilution of virus (plated in duplicate), plus a few control plates or wells. The day before the plaque assay, split BHK cells into 6-well plates containing $\sim 6 \times 10^{6}$ cell/plate $=1 \times 10^{6}$ cells/well. In general, the use of 6 -well plates has replaced the use of individual flasks; however when learning the technique the use of flasks in much simpler.

Note: The number of cells required is determined by the confluency required at the time of the assay. Because confluency is related to the area the cells cover, this number is manipulated by knowing the area of the vessel the cells will grow on. Thus, the area of the flasks (rectangular) or wells (circular) will vary but the number of cells $/ \mathrm{cm}^{2}$ is constant. (e.g., $1 \times 10^{6}$ cells. For a 6- well plate, each well is $9.6 \mathrm{~cm}^{2}$ seeded with $1 \times 10^{6}$ cells/well $\times 6$ wells for a total of $\sim 58 \mathrm{~cm}^{2}$ onto which a total of $\sim 610^{6}$ cells is seeded. These numbers are relative to every specific culture of any cell line and may need to be adjusted up or down. The important thing is the \% confluency on the day of the assay during which the cells should still be in log phase.

2. Allow cell monolayers to become $\sim 80 \%-90 \%$ confluent by the time of the plaque assay.

Note: If the cells are ready in the morning and the assay is to be done in the afternoon, the cells can be stored at room temperature with the caps closed tightly, or moved to a $28{ }^{\circ} \mathrm{C}$ incubator to slow growth.

3. Remove the virus to be titered from the freezer and thaw on ice.

4. Fill the required number of dilution tubes with $900 \mu$ diluent (SVHR diluent; $1 \times$ PBS-D/3\% FBS (see Recipes). You need one tube/dilution. One tube for the control (not infected) and one for the positive infected control.

5. Prepare serial dilutions of the virus by adding $100 \mu \mathrm{l}$ virus to the first tube containing $900 \mu \mathrm{l}$ of diluent $\left(10^{-1}\right)$, vortex that dilution at full speed, removing $100 \mu \mathrm{l}$, and adding it to the next dilution tube $\left(10^{-2}\right)$. Continue this process until the desired dilutions have been made. Change pipet tips each time to avoid "carry-over" effect of contaminating virus.

Note: Dilutions should be made immediately prior to use. Virus and dilutions should be kept on ice at all times.

6. Once the dilutions have been made, pour growth media out of flasks (into a sterile waste beaker) and pipet out of plates with a serological pipet (leave enough liquid to cover the monolayer) and infect each flask or well of a 6-well plate with $200 \mu \mathrm{l}$ of the appropriate dilution. In this case, the area of the vessel no longer matters because the calculation will convert plaques at each dilution to PFU/ml.

7. Do not let monolayers dry out while adding virus-i.e., do not pour/pipette media off too many flasks/plates at one time or try to drain every drop. DRY MONOLAYERS ARE DEAD MONOLAYERS.

8. Place flasks on a rocking platform at room temperature for one hour. Do not rock plates; the liquid will only swirl around the edge of the well. Place the plates at the appropriate temperature, $38{ }^{\circ} \mathrm{C}$ for BHK cells and hand rock every $15 \mathrm{~min}$. 
Note: The caps on the flasks should be tightened while they are rocking since they are not in the appropriate $\mathrm{CO}_{2}$ environment unless they are vented, then place these in the incubator.

9. After an hour of rocking/incubating, remove the inoculum (pipette) and overlay the monolayer with $7 \mathrm{ml}$ of a $1: 1$ mixture of $2 \%$ agarose in $\mathrm{dH}_{2} \mathrm{O}$ and complete $2 \times$ EMEM with $7 \mathrm{ml}$ for $\mathrm{T}-25 \mathrm{~cm}^{2}$ flasks and $2 \mathrm{ml}$ for each well of a 6-well plate.

Notes:

a. The agarose should be hot enough that it will not solidify too quickly, but cool enough to allow one to touch the bottle before mixing with the medium $\left(\sim 60-70{ }^{\circ} \mathrm{C}\right)$. Bottles of media at the correct temperature should not feel excessively hot to the touch. Do not try to move flasks/plates before the overlay has solidified, because the cell monolayer will tear. Solidified agar will appear cloudy.

b. Not all agarose is tolerated by cells in culture. In general, agarose formulated for gel electrophoresis or chromatography is not suitable for tissue culture. Use Sigma agarose () (Sigma-Aldrich, St Louis, MO, catalog number: A6013).

10. Incubate flasks for 2 days at $37^{\circ} \mathrm{C}, 5 \% \mathrm{CO}_{2}$.

Note: Before staining monolayers, hold the flasks up to the light to see if plaques are visible. The plaques will appear more opaque than the rest of the monolayer. Visible plaques are an indication that the assay has worked up to this step.

11. To stain the monolayer, add $5 \mathrm{ml}$ of $1: 1$ mixture of $2 \%$ agarose in $\mathrm{dH}_{2} \mathrm{O}$ and $2 \times$ PBS-D with $3 \%$ neutral red stain ( $3 \%$ of the total amount of agarose required). Cover the flasks to protect cells from light.

Note: Cells become light sensitive after they take up neutral red and should be protected from light.

12. If necessary, when the plaques are faint, return flasks (plates) to $37^{\circ} \mathrm{C}$ for $4 \mathrm{~h}$ or $28^{\circ} \mathrm{C}$ overnight prior to counting plaques.

Note: You should expect to see clear plaques surrounded by red, living cells. The number of plaques per flask should roughly follow the dilutions made (e.g., 1 plaque on $10^{-6}$ flask, 10 plaques on $10^{-5}$ flask, and 100 plaques on $10^{-4}$ flask). Plates can be used to produce duplicates (6-well plates) or triplicates (24-well plates). If there are no plaques, check the monolayers under the microscope, the cells may be lysed.

13. Count plaques and calculate the titer.

14. To calculate the virus titer: e.g., with 2 plaques at -7 dilution and an inoculum of $200 \mu \mathrm{l}$, convert this to plaques $/ \mathrm{ml}$ or 2 plaques $\times 1 / 200 \mu \mathrm{l} \times 10^{3} \mu \mathrm{l} / 1 \mathrm{ml}=10$ plaques $/ \mathrm{ml}$ from a $1 / 10^{-7}$ dilution $=10 \times 10^{7}$ or $1 \times$ $10^{8} \mathrm{PFU} / \mathrm{ml}$. Thus the equation is \#plaques/dilution factor $(\mathrm{ml}) \times$ volume of inoculum $(\mathrm{ml})=\mathrm{PFU} / \mathrm{ml}$. Unless the number of virus particles = number of plaques $/ \mathrm{ml}$ then this unit is a plaque forming unit. This will be explained in the section calculating the particle to PFU ratio.

Note: If there are no plaques but the positive control worked then the sample has no virus or the incorrect dilutions were plated. If there are no plaques in the control sample check the cells under the microscope for lysis, lysed cells will not take up stain or produce a plaque. Cell lysis will occur if the osmolarity and tonicity of the cultures are not correct. Crystals of stain mean that the agarose was too hot when it was added. Agarose that is too hot will also kill the cells.

\section{Sindbis virus infection of vertebrate and invertebrate cells}

\section{Sindbis virus infection of BHK cells}

1. Subculture BHK cells the day prior to infection such that the monolayer is $\sim 90 \%$ confluent at the time of infection.

2. Calculate the amount of virus needed for the desired multiplicity of infection (MOI).

No. cells $\times$ MOI $=$ PFU needed.

For a single cycle $\mathrm{MOI}=10$, stock virus $\mathrm{MOI}=0.01$

For $75 \mathrm{~cm}^{2}$ flask, the number of cells is $\sim 2 \times 10^{7}$ cells

For $25 \mathrm{~cm}^{2}$ flask, the number of cells is $\sim 6 \times 10^{6}$ cells

For a 6-well plate, the number of cells is about $1 \times 10^{6}$ cells/plate.

Plates are also used if a small amount of inoculum is used, e.g., stock virus volume titer is too low to infect too many cells and the virus must be amplified before use. 
3. Remove the virus from $-80^{\circ} \mathrm{C}$ freezer and thaw the vial on ice. Dilute inoculum to the desired concentration in $1 \times$ PBS-D/3\% FBS. Refreeze unused stock virus.

Notes:

a. A total volume of at least $1 \mathrm{ml}$ is required for infection of $75 \mathrm{~cm}^{2}$ monolayer, and a minimum of 200 $\mu l$ is required for a $25 \mathrm{~cm}^{2}$ monolayer. A minimum of $200 \mu \mathrm{l}$ is required for a 6 -well plate. Close the cap tightly and secure to rocker platform. Do not rock plates.

b. SVHR is heat stable however, many other strains and mutants of Sindbis are not, and thus must be thawed on ice to retain infectivity.

4. Place flask on a rocking platform for $1 \mathrm{~h}$ at room temperature, with caps tightened. Alternatively, infect in the incubator at $37^{\circ} \mathrm{C}$ with intermittent hand rocking.

5. Remove inoculum and add fresh, complete $1 \times$ E-MEM media. Add 5-7 ml media to a 75- $\mathrm{cm}^{2}$ monolayer or $3 \mathrm{ml}$ to a $25-\mathrm{cm}^{2}$ monolayer. Leave the caps loosened during incubation to allow for $\mathrm{CO}_{2}$ exchange. If more concentrated virus is desired, add $3 \mathrm{ml}$ medium to a $75-\mathrm{cm}^{2}$ monolayer. Do not allow the monolayer to dry out.

6. Virus should be harvested once CPE becomes evident, which is generally between 18 (BHK) and $24 \mathrm{~h}$ (C7-10) post-infection.

Note: Cell lines will differ in the time period in which CPE is demonstrated. Some indicators of CPE in BHK cells include the cells becoming long and thin, cytoplasm with a "foamy" appearance, aggregations of cell nuclei, and, in advanced stages, cell lysis. Do not allow the cells to lyse for any type of virus analysis work.

7. Remove medium from flasks to conical centrifuge tubes (Corning, $15 \mathrm{ml}$ Fisherbrand Cat \# 05-539-5 or $50 \mathrm{ml}$ centrifuge tubes, Fisherbrand Cat \# 05-539-6). Combine like samples if desired. Spin samples for 10 min in a tabletop centrifuge at $\sim 700 \times g$ to remove cell debris. Decant virus to a new tube and bring the solution to $10 \%$ glycerol which acts as a cryoprotectant. Aliquot the virus supernatant into tubes appropriate for freezing and flash freeze virus using liquid $\mathrm{N}_{2}$.

8. Store virus at $-80^{\circ} \mathrm{C}$.

Note: Membrane containing viruses will undergo a freeze-thaw at $-65{ }^{\circ} \mathrm{C}$ due to phase transition in ice. Thus a freezer failure resulting in warming to $-65^{\circ} \mathrm{C}$ should be considered a thaw. Sindbis virus will lose some titer ( 0.5 logs) upon freeze-thaw but is still infectious.

\section{Sindbis virus infection of C7-10 cells}

Mosquito cells are used when a comparative analysis of virus titers from the invertebrate host are required. To infect mosquito cells, a confluent monolayer of single cells (no clumps) must be formed. Mosquito cells do not adhere well to the substrate, and tend to lift from the flasks regardless of the medium used. To temporarily circumvent this problem, mosquito cultures can be starved for serum for one hour, which causes the cells to adhere to the substrate more tightly. Mosquito cultures in our lab have been adapted to use in E-MEM, however, all other treatments of the cells are consistent with cells which are in other insect media.

1. Spin down for $5 \mathrm{~min}$ at 200-500 $\times \mathrm{g}$ approximately $1 \frac{1 / 2}{2}-75 \mathrm{~cm}^{2}$ flasks of cells per $1-75 \mathrm{~cm}^{2}$ flask needed for infection.

Note: Mosquito cells grow as semi-suspension cultures and are easily removed from the flask by tapping the flask against a hard surface, or alternatively by pipetting up and down with a 5-10 ml pipet. Do not spin excessively as the cells will die during pelleting or resuspension. Some cells will be lost during the process.

2. Wash the cell pellet once with $1 \times$ PBS-D to remove any remaining medium.

3. Resuspend the final cell pellet in $1 \mathrm{ml} /$ flask needed for infection, of E-MEM medium deficient in FBS.

4. Count the cells using a hemocytometer.

5. Aliquot approximately $6 \times 10^{7}$ cells per $75-\mathrm{cm}^{2}$ flask with enough medium (without FBS) to cover the monolayer.

6. Incubate the flask of cells at $28^{\circ} \mathrm{C}$ for one hour, or until cells are well attached to the surface of the flask.

7. Once cells are attached, remove medium and add the desired amount of virus to the monolayer. Close caps tightly. 
8. Rock the flask slowly at room temperature for one hour.

Note: Rocking slowly is critical to keep a minimum number of cells from lifting from the flask.

9. Most of the cells should remain attached to the flask after rocking. If cells have lifted from the monolayer they should be removed with the inoculum.

10. Fresh, complete E-MEM medium should be added to each flask.

Note: To increase the concentration of virus, minimize the volume of fresh medium added to the flasks. A minimum of $3 \mathrm{ml}$ medium $/ 75 \mathrm{~cm}^{2}$ is required to cover the cells and support metabolism. Take care that the flasks are level to ensure complete coverage of the monolayers.

11. Virus may be harvested from 24 to $72 \mathrm{hpi}$ depending on the multiplicity (MOI) used. Cytopathic effect (CPE) will not be evident in mosquito cells, in which case virus will be harvested based on time postinfection rather than $\mathrm{CPE}$.

12. For normal storage: Harvest virus and store in sterile $10 \%$ glycerol. For best preservation of the virus titer quick freeze tubes in liquid $\mathrm{N}_{2}$.

Note: Virus frozen and thawed will lose 1/3 to 1/5 log of titer. This is not a significant loss for use to infect cells. For preservation of the highest infectivity level, virus can be stored at $4{ }^{\circ} \mathrm{C}$ for up to 5 days in neutral $\mathrm{pH}$ buffer. This method preserves the most infectivity and is used for virus to be analyzed in structural studies and for the calculation of particle to PFU ratios.

\section{Purification of Sindbis virus}

\section{Purification and concentration by isopycnic centrifugation}

The virus supernatant is harvested into conical tubes and cell debris is removed from the supernatant by lowspeed centrifugation. This is a critical step and if it is omitted, too much debris will interfere with the following gradient purification steps. Clarify virus supernatant by centrifugation in the appropriate size conical tube for 10 min at $1,800 \times g$.

1. Virus supernatant is combined into an appropriate size container omitting addition of the glycerol.

Note: From this step forward, you should not consider your samples sterile. This is not usually a problem and antibiotic is added to the $2 \times$ E-MEM media.

2. Determine the number of gradients which will be needed.

Typically, $20 \mathrm{ml}$ of virus is layered onto the initial potassium tartrate step gradient in the $38 \mathrm{ml}$ tubes. This gradient is formed by carefully layering $12 \mathrm{ml}$ of $15 \%$ potassium tartrate onto a layer of $6 \mathrm{ml}$ of $35 \%$ potassium tartrate, or making a $10 \%$ to $35 \%$ continuous potassium tartrate gradient. Read the manufacturer's manual for instructions on use of the gradient former. The tubes are placed into the rotor buckets and weighed upright (we use a small beaker cushioned with tissue). PBS-D is added drop- wise to balance the tubes. Take special care to weigh the buckets and tubes, and load the centrifuge rotor according to the manufacturer's tolerances and specifications found in the manual. Failure to do so can result in severe damage to the rotor and the instrument.

Note: The rotor, buckets and solutions should be pre-chilled to $4{ }^{\circ} \mathrm{C}$. If an odd number of gradients are required a "blank" gradient is made and overlaid with buffer to balance the rotor.

3. The gradients are centrifuged overnight (this is purely for convenience) at $24,000 \mathrm{rpm}$ in an SW-28 Beckman rotor (or $100,000 \times g$ ) and $4{ }^{\circ} \mathrm{C}$.

4. After the run is completed, remove a tube carefully from the bucket and attach to a ring stand using a small tube clamp. A virus band of iridescent blue should be visible at the potassium tartrate $15 \%-35 \%$ step interface when the gradient is illuminated from the side with a hand held light of 20 watts. See Figure 4 Density gradient purified Sindbis virus band. Repeat for each of the gradients.

5. Collect the band by puncturing the bottom of the tube and letting the tartrate solution flow into a waste beaker, while collecting the virus band into a $2 \mathrm{ml}$ cryotube. Discard the remaining solution. Alternatively, the band can be collected from the side of the tube using a needle and syringe.

6. Pool the virus-containing samples and dilute with 1.5 volumes of ice-cold PBS-D. This solution should be less dense than $15 \%$ potassium tartrate. To check that your concentration is correct, your virus solution should not sink into an aliquot of $15 \%$ potassium tartrate. 
7. This diluted virus is then layered over a continuous $15 \%-35 \%$ potassium tartrate linear gradient of a volume not less than $3 / 4$ of the added virus sample. The first gradient may be a step or linear gradient but the second should be a linear one. Do not overfill.

8. The continuous gradients are run for $2 \mathrm{~h}$ at 26,000 rpm in an SW 40ti Beckman rotor $(120,000 \times g)$ and the virus band collected as described in Step D6 above. The virus band should appear about 1/3 down the length of the tube. The virus band may be stored at $4{ }^{\circ} \mathrm{C}$ in the tartrate solution. The refractive index of the final virus-tartrate solution is 1.3665 which is 28\% tartrate (Rumble, 2005).

9. Collect a sample of the virus to titrate by plaque assay and to determine protein concentration by BCA assay (Pierce ${ }^{\mathrm{TM}}$ Rapid Gold BCA Protein Assay Kit, Thermo Fisher).

Note: Properly grown and purified SVHR should give a particle/PFU value of $\sim 1$.

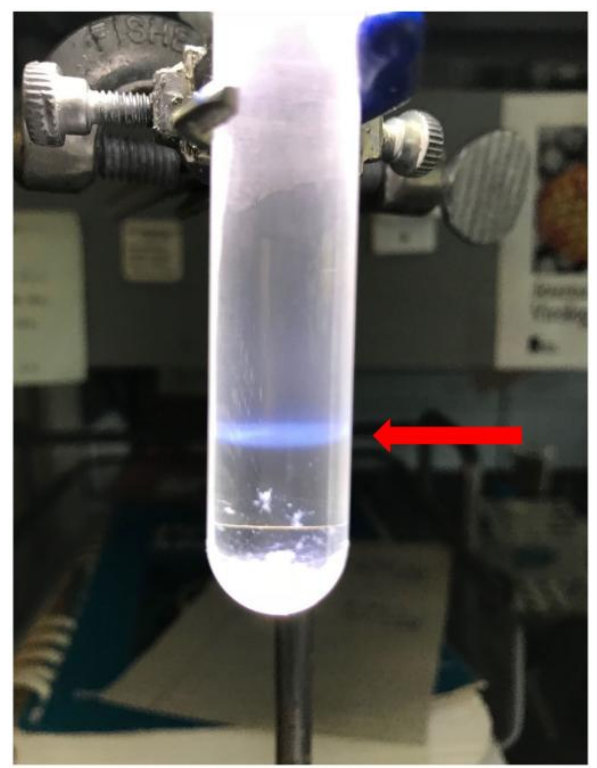

Figure 4. Shown is the opalescent blue band of purified Sindbis virus in a 15-35\% potassium tartrate gradient.

Note the flocculent pellet at the bottom of the tube. This will be removed after the second K-tartrate gradient.

\section{Concentration of virus by Polyethylene glycol (PEG) precipitation}

Note: This is an alternative purification step used to concentrate the virus particles but infectivity will be lost.

1. Infect BHK cells with Sindbis virus as previously described for virus purification. The number of flasks infected will vary depending on how much virus you need.

2. Pour culture medium into a centrifuge tube.

3. Spin supernatant for clarification, removing cells and cell debris (from this step proceed as in Steps D2D9 in virus purification protocol.

4. Transfer supernatant to a fresh tube.

5. Add 0.25 volumes of $40 \%$ polyethylene glycol- 8000 in $2 \mathrm{M} \mathrm{NaCl}$ and mix well.

6. Incubate about $24 \mathrm{~h}$ at $4{ }^{\circ} \mathrm{C}$ for virus precipitation.

7. Centrifuge at $10,000 \mathrm{rpm}(12,000 \times \mathrm{g})$ for $10 \mathrm{~min}$.

8. Discard the supernatant into a waste beaker and drain well (invert the tube and use a kimwipe to absorb any traces of PEG).

9. Re-dissolve the pellet in $5 \mathrm{ml}$ of $1 \times$ PEG buffer.

10. Transfer to a Kimax glass centrifuge tube.

11. Centrifuge at $12,000 \times g$ for $10 \mathrm{~min}$ (Sorval)-this is a further clarification step.

12. Use the supernatant for gradient purification as described (from this step proceed as in Steps D2-D9 in virus purification protocol. 
Notes:

a. We did not use PEG concentration of Sindbis virus in our proteomic protocol but include the results in this protocol to demonstrate the importance of purification of infectious virus particles compared to noninfectious particles to extrapolate conclusions on functions of the virus system in question.

b. We find that using the SVHR strain of Sindbis virus, PEG concentration followed by isopycnic purification increases the particle/PFU ratio by 10 fold. This increase in the number of non-infectious particles in the interpretation of the experimental outcomes should be seriously evaluated and noted in the results.

\section{E. Calculation of particle to PFU ratio}

1. A precise protein concentration of the purified virus is required for this calculated value to be accurate. The tartrate solution or PEG will interfere with this assay; the sample must be diluted 1:10.

2. SVHR virus proteins MW in Daltons = total combined weight of structural proteins $(C, E 2$ and E1 $)=130$ KDa (by direct BCA measurement, use this measured number and not the calculated value).

3. This value is multiplied by 240 copies/virus particle ( $\mathrm{T}=4$ particle:60 $\mathrm{T}=240$ copies). See Johnson and Speir (1997) for T calculation.

$130 \mathrm{KDa}$ (total virus protein, see Step E2) $\times 240$ (copies/particle see Step E3 above) $=3.12 \times 10^{7}$ Da of protein/virus particle

Convert from Da to grams [1 Dalton $=1.66 \times 10^{-24} \mathrm{~g}(\mathrm{CRC}$ tables $)$ ]

$3.12 \times 10^{7} \mathrm{Da} /$ virus particle $\times 1.66 \times 10^{-24} \mathrm{~g} / \mathrm{Da}=5.18 \times 10^{-17} \mathrm{~g} /$ particle

e.g., if you have $10^{11} \mathrm{PFU} / \mathrm{ml}$ SVHR you will have $208 \mu \mathrm{g} / \mathrm{ml}$ of protein (measured by BCA assay)

$=2.08 \times 10^{-4} \mathrm{~g} / \mathrm{ml}$.

Note: PFU and particles are not the same unit. PFU or plaque forming units is a measure of infectivity of the virus because all virus particles are not infectious. The number of particles refers to the number of physical particles in a solution, which is normally greater than the number of PFU.

Calculate particles/ml:

$2.08 \times 10^{-4} \mathrm{~g} / \mathrm{ml} / 5.18 \times 10^{-17} \mathrm{~g} /$ particle $=0.4 \times 10^{13}$ particles $/ \mathrm{ml}$

$0.4 \times 10^{13}$ particles $/ \mathrm{ml} / 1 \times 10^{11} \mathrm{PFU} / \mathrm{ml}=0.4 \times 10^{2}$ particles $/ \mathrm{PFU}=40$ particles $/ \mathrm{PFU}$

Note: For Sindbis SVHR the particle/PFU ratio from BHK or C7-10 cells should be $\sim 1$ part/PFU.

\section{F. Mass spectrometry and proteomic analysis}

1. To visually determine if the sample contains contamination a sample of the purified population was then visualized by transmission electron microscopy to check for contaminating cellular organelles or membrane fragments (Coombs and Brown, 1987). This method is beyond the scope of this protocol but detailed in the reference provided above.

2. Additionally, to check for co-purified protein contaminants, check protein content by running $\sim 10 \mu$ of virus on a $4-12 \%$ Bis-Tris SDS-PAGE gradient gel (Invitrogen, Novex) as described by the manufacturer.

3. Stain the gel with silver in the method of Wray or with coomassie blue (Wray et al., 1981). Excise the visualized bands (silver stain only) and perform an in-gel digestion prior to LC-MS/MS analysis for protein identification (Glaros et al., 2015).

\section{Protein extraction and digestion}

Viral preparations and their respective negative controls, medium from the cell monolayers harvested prior to infection were processed for LC-MS/MS analysis using the filter-aided sample preparation (FASP) method (Wiśniewski et al., 2009).

1. Following purification, determine the total protein concentration using a Pierce BCA protein assay kit, following the manufacturer's instructions.

2. Normalize all preparations using sterile PBS to $0.5 \mu \mathrm{g} / \mu \mathrm{l}$; aliquot out $10 \mu \mathrm{g}$ of each sample into Lo-bind Eppendorf tubes.

3. For each sample, mix $10 \mu \mathrm{g}$ of total protein $(20 \mu \mathrm{l})$ 1:1 with M-PER supplemented with $50 \mathrm{mM}$ dithiothreitol (DTT) and heat at $95^{\circ} \mathrm{C}$ in a heat block at $400 \mathrm{rpm}$ for $10 \mathrm{~min}$ to reduce and denature proteins. 
4. Cool samples to room temperature, and mix with $200 \mu$ of UA buffer (8 M urea, $100 \mathrm{mM}$ Tris- $\mathrm{HCl}, \mathrm{pH}$ 8.5).

5. Apply each preparation to a $30 \mathrm{kDa}$ filter spin column (Millipore-Ultracell YM-30), and centrifuge at $14,000 \times g$ for $30 \mathrm{~min}$ at room temperature to collect all proteins onto the filter membrane.

6. Alkylate proteins by adding $100 \mu \mathrm{l}$ of iodoacetamide (IAA) solution (0.05 M IAA in UA buffer) to each filter membrane and incubate at room temperature in the dark for $20 \mathrm{~min}$. Following alkylation, centrifuge the samples at $14,000 \times g$ for 20 min to remove the alkylation solution.

7. Wash each sample by applying $100 \mu \mathrm{l}$ of UA buffer to the filter and centrifuging at room temperature at $14,000 \times g$ for $30 \mathrm{~min}$. Repeat this washing step two more times for a total of three washes. Then wash three more times each with $100 \mu$ l of $100 \mathrm{mM}$ triethylammonium bicarbonate (TEAB).

8. To digest the captured protein, apply $100 \mu \mathrm{l}$ of a trypsin digestion solution (Trypsin/Lys-C prepared in 100 $\mathrm{mM}$ TEAB to $10 \mu \mathrm{g} / \mathrm{ml}$ ) on each membrane and incubate in sealed tubes overnight (wrap the closed tube caps with parafilm for a better seal) in a heat block at $37^{\circ} \mathrm{C}, 400 \mathrm{rpm}$.

9. After incubation, collect the peptides for LC-MS/MS analysis. Place filter units in a new, clean tube and centrifuge each tube for $30 \mathrm{~min}$ at $14,000 \times \mathrm{g}$ at room temperature. Wash the membrane by centrifugation one time with $50 \mu \mathrm{l}$ of $100 \mathrm{mM}$ TEAB and once with $50 \mu \mathrm{l}$ of $0.5 \mathrm{M} \mathrm{NaCl}$. Collect both of these washes and pool with the final peptide eluate.

10. Acidify each sample with $10 \%$ trifluoroacetic acid until the final $\mathrm{pH}$ is $\sim 2-3$.

11. Prior to mass spectrometric analysis, desalt each sample using Pierce C18 spin columns according to the manufacturer's directions. Eluate from the desalting process should be dried to completeness in a clean Lo-bind Eppendorf microcentrifuge tube using a SpeedVac at $30{ }^{\circ} \mathrm{C}$ and stored at $-80^{\circ} \mathrm{C}$ until LC-MS/MS analysis.

\section{LC-MS/MS data acquisition}

1. Reconstitute dried peptides in "A Buffer” (3\% acetonitrile/0.1\% formic acid) and resolve on VIRGIN Picofrit $15 \mathrm{~cm} \times 75 \mu \mathrm{m}$ ID HPLC column packed with $5 \mu \mathrm{m}$ BioBasic C18 particles $300 \AA$ using a multistep gradient [e.g., 130 min; 0-5 min: 5-10\% B, 6-110 min: 10-35\% B, and 111-130 min: 35-95\% B]. A virgin or unused column is important to ensure that all peptides identified are from the sample and not from a previous LC-MS/MS run which could result from 'carry over' if using a column that already had a sample applied. The liquid chromatography gradient should be chosen to allow for adequate separation without excessive time. These parameters depend upon the column and instrument used for analysis. For the gradient, the A buffer is 3\% acetonitrile/0.1\% formic acid and the B buffer is $95 \%$ acetonitrile/ $0.1 \%$ formic acid. Tryptic peptides should be analyzed in at least technical triplicates.

2. For the Orbitrap ELITE the following configurations were used. This should serve as a guide for similar instrument parameters if using other mass spectrometers. These parameters are instrument specific and you should consult the instrument's manufacture or the literature for recommendations. Generic settings established from the literature used for bottom up (tryptic peptide analysis) proteomics are likely adequate. A variety of instrument methods have been curated and peer-reviewed which are available at www.massspectrometrymethods.org.

\section{Example instrument settings used for an orbitrap ELITE}

a. Orbitrap MS1 scans are performed at a resolution of 120,000 at $400 \mathrm{~m} / \mathrm{z}$, with a scan range of 110 $2,000 \mathrm{~m} / \mathrm{z}$.

b. The top 20 precursors are selected for MS2 data-dependent fragmentation. An MS2 spectrum is acquired using the iontrap scanning in normal mode (Top 20 Method).

c. The minimum signal required to trigger a data-dependent scan is 5000 .

d. Collision-induced dissociation (CID) is used to generate MS2 spectra with the following settings: normalized collision energy 35\%, default charge state 2, isolation width $2 \mathrm{~m} / \mathrm{z}$, and activation time 10 ms.

e. AGC target is set to $1 \times 10^{6}$ for MS and $5 \times 10^{4}$ for MS/MS with a maximum accumulation time of $200 \mathrm{~ms}$.

f. Dynamic exclusion is set for $60 \mathrm{~s}$ for up to 500 targets with a 5 ppm mass window. 
g. A lock mass of 445.120025 is used for internal calibration to improve mass accuracy.

\section{Data Processing}

1. Process spectra data using Proteome Discoverer with the embedded SEQUEST search algorithm against a Sindbis virus polyprotein database (Uniprot ID: P03317) merged with either Homo sapiens (RefSeq Tax ID: 9606) or Cricetulus griseus (RefSeq Tax ID: 10029). Download the Aedes albopictus-deducted proteome (Chen et al., 2015) data from VectorBase (Giraldo-Calderón et al., 2015) and additional peptides from the NCBI TSA database.

2. Organize the non-redundant proteomes on excel spreadsheets (Ribeiro et al., 2004) and annotate as described previously (Karim et al., 2011). Merge the resulting FASTA file with the SINV polyprotein and use it to search against the SINV mosquito preparations.

3. Set dynamic modifications for carbamidomethylation of cysteine [+57.02 Da], oxidation of methionine [+15.99 Da], and N-terminal acetylation [+42.011].

4. MS/MS spectra are searched with a precursor mass tolerance of $10 \mathrm{ppm}$ and a fragment mass tolerance of 0.6 Da.

5. Trypsin is specified as the protease with a maximum number of missed cleavages set to 2 .

6. False discovery rate using PERCOLATOR (Kall et al., 2007) is set to $<1 \%$ to score high confidence peptide identifications.

7. Perform grouping and functional analysis using the PANTHER classification system for the human background only with each protein id's accession number (Mi et al., 2016).

\section{Recipes}

\section{Complete E-MEM, $1 \times$ and $2 \times$}

Note: Do not warm 2× MEM until the supplements have been added, it will precipitate.

$10 \%$ heat-inactivated fetal bovine serum (FBS; any suitable FBS, we test sample lots of FBS prior to purchase)

$5 \%$ tryptose phosphate broth (TPB; see Recipe 11; This is only added to the BHK cells)

$0.02 \%$ L-glutamine (see Recipe 3 for $100 \times$ )

$1 \times$ gentamicin sulfate (see Recipe 2 for $100 \times$ )

\section{For $1 \times$ medium}

Mix the following:

$400 \mathrm{ml}$ 2× E-MEM (see Recipe 1)

$400 \mathrm{ml} \mathrm{TC} \mathrm{H}_{2} \mathrm{O}$

$80 \mathrm{ml}$ FBS

$8 \mathrm{ml}$ L-glutamine

*8 ml gentamicin sulfate

Store up to 2 weeks at $4{ }^{\circ} \mathrm{C}$

*Note: Gentamicin is added to medium only for virus growth and not for general maintenance of any of the cell cultures.

For $2 \times$ medium (used to titer viruses by plaque assay)

Prepare $536 \mathrm{ml}$ medium by mixing the following:

$400 \mathrm{ml} 2 \times$ E-MEM (incomplete, serum-free; see Recipe 1)

$80 \mathrm{ml}$ FBS

$40 \mathrm{ml} \mathrm{TPB}$

$8 \mathrm{ml} 100 \times$ L-glutamine

$8 \mathrm{ml} 100 \times$ gentamicin sulfate

Store up to 6 months 
IMPORTANT NOTE: Complete medium with supplements are not true percent solutions. The percentage indicated represents the percentage of the original volume of medium. This also holds for any other supplements added to the medium. For example, if the initial volume of the medium is $400 \mathrm{ml}, 10 \% \mathrm{FBS}$ is $40 \mathrm{ml}$. Addition of other supplements, such as 5\% TPB would be $20 \mathrm{ml}$ TPB, bringing the total volume to $460 \mathrm{ml}$. If problems arise with the cell cultures, growth of the virus, or plaque formation, discard old solutions and make fresh solutions.

\section{Gentamicin sulfate, $100 \times$}

Dilute 0.5 g gentamicin sulfate up to $100 \mathrm{ml}$ in tissue-culture-grade water

Store up to 6 months at $4{ }^{\circ} \mathrm{C}$

Dilution to $1 \times$ will give a final concentration of $50 \mu \mathrm{g} / \mathrm{ml}$. If necessary, $100 \mu \mathrm{g} / \mathrm{ml}$ may be used CAUTION: Antibiotics can become contaminated. If persistent problems are experienced with contaminated cultures, test all solutions in the absence of antibiotics.

\section{L-glutamine, $100 \times$}

Weigh out $2.92 \mathrm{~g} \mathrm{~L}$-glutamine and dissolve in a total volume of $100 \mathrm{ml} 1 \times$ PBS-D (see Recipe 7 for 10×)

Filter sterilize and divide into 50 -ml aliquots in 100 -ml bottles

Store frozen up to 6 months; once thawed, discard after 2 weeks

Note: Glutamine is essential and very labile. It is thus added to already complete medium as a precaution.

\section{HEPES (pH 7.2-7.4), $1 \mathrm{M}$}

Weigh out $238.3 \mathrm{~g}$ HEPES and dissolve in a total volume of $1 \mathrm{~L}$ tissue-culture grade water

Adjust $\mathrm{pH}$ to 7.2-7.4 with $\mathrm{NaOH}$

Autoclave for $30 \mathrm{~min}$ to sterilize

Store up to 1 year at room temperature

\section{PEG Buffer}

$0.4 \mathrm{M} \mathrm{NaCl}$

0.01 M Tris Buffer pH 7.0

0.001 M EDTA

\section{Neutral red stock solution, $2 \%$}

Dissolve $2 \mathrm{~g}$ neutral red and adjust the volume to $100 \mathrm{ml}$ with tissue-culture-grade water

Stir overnight at room temperature and filter sterilize

Store up to 1 year at room temperature

Notes:

a. Some stain will be lost in the filtration process and each batch may differ. This stain is quite viscous and may require more than one filter to sterilize the entire quantity.

b. Alternatively, neutral red stock solution may be purchased ready made from many suppliers.

\section{PBS-D, 10 $\times$}

$2.0 \mathrm{~g} \mathrm{KCl}$

$2.0 \mathrm{~g} \mathrm{KH}_{2} \mathrm{PO}_{4}$

$80.0 \mathrm{~g} \mathrm{NaCl}$

11.3 g Na $2 \mathrm{HPO}_{4}$ or 21.6 g Na $2 \mathrm{HPO}_{4} \cdot 7 \mathrm{H}_{2} \mathrm{O}$

Tissue-culture-grade $\mathrm{H}_{2} \mathrm{O}$ to $1 \mathrm{~L}$

Autoclave for $20 \mathrm{~min}$

Dilute to $1 \times$ with sterile tissue-culture-grade water

Store up to 1 year at room temperature

Note: PBS-D is PBS (phosphate buffered saline) deficient in calcium and magnesium. This can be made as a $1 \times$ solution. Also see annotations to the recipe for PBS with calcium and magnesium. It is critical that the $\mathrm{pH}$ 
of the $1 \times$ solution is $\sim 7.4$ because low $p H$ will inactivate all Alphaviruses.

\section{PBS with calcium and magnesium, $1 \times$}

Prepare solutions 1 and 2 (which are $10 \times$ stock solutions) and autoclave separately for 20 min Note: PBS cannot be made as a concentrated solution, it will precipitate.

\section{Solution 1:}

$1.0 \mathrm{~g} \mathrm{CaCl}_{2}$

$1.3 \mathrm{~g} \mathrm{CaCl}_{2} \cdot 2 \mathrm{H}_{2} \mathrm{O}$

$2.0 \mathrm{~g} \mathrm{KH}_{2} \mathrm{PO}_{4}$ (dissolve separately, then add to mixture)

$1.0 \mathrm{~g} \mathrm{MgCl}_{2} \cdot 6 \mathrm{H}_{2} \mathrm{O}$

$80.0 \mathrm{~g} \mathrm{NaCl}$

Adjust volume to $1 \mathrm{~L}$ with tissue-culture-grade $\mathrm{H}_{2} \mathrm{O}$

\section{Solution 2:}

21.6 g Na $2 \mathrm{HPO}_{4} \cdot 7 \mathrm{H}_{2} \mathrm{O}$ or $11.3 \mathrm{~g}$ anhydrous $\mathrm{Na}_{2} \mathrm{HPO}_{4}$

Adjust volume to $1 \mathrm{~L}$ with tissue-culture-grade $\mathrm{H}_{2} \mathrm{O}$

For $1 \times$ solution:

Add $50 \mathrm{ml}$ solution 1 to $400 \mathrm{ml}$ tissue-culture-grade water

Mix, then add $50 \mathrm{ml}$ solution 2

Do not directly mix solutions 1 and 2 together: salts will precipitate

Store solutions at room temperature up to 1 year or until salts begin to precipitate

Check that the final $\mathrm{pH}$ of the $1 \times$ solution is $~ 7.2$ to 7.4

IMPORTANT NOTE: Do not adjust the $\mathrm{pH}$ of the $10 \times$ solutions 1 and 2, because this will result in the wrong $\mathrm{pH}$ for the $1 \times$ solution. It is critical that all solutions that Sindbis virus comes in contact with are neutral $\mathrm{pH}$. Acidic $\mathrm{pH}$ quickly inactivates the virus.

\section{Phenol red, $0.5 \%$}

Note: Do not confuse with neutral red.

Dissolve $1 \mathrm{~g}$ phenol red in $200 \mathrm{ml}$ tissue-culture-grade water

Filter sterilize and store up to 1 year at room temperature

\section{SVHR diluent (used to dilute virus to be titrated by plaque assay)}

Supplement $1 \times$ PBS-D (see Recipe 7 for $10 \times$ ) to $3 \%$ FBS with heat-inactivated fetal bovine serum (FBS) Store up to 2 months at $4{ }^{\circ} \mathrm{C}$

\section{Trypsin stock, $0.25 \%$}
$0.5 \mathrm{~g}$ trypsin
$0.2 \mathrm{~g}$ disodium EDTA
$0.6 \mathrm{~g}$ phenol red

Adjust volume to $200 \mathrm{ml}$ with $1 \times$ PBS-D (see Recipe 7 for $10 \times$ )

Adjust $\mathrm{pH}$ with $1 \mathrm{~N} \mathrm{NaOH}$ until a cherry red color is achieved

Divide into 25-ml aliquots

Store frozen up to 6 months at $-20^{\circ} \mathrm{C}$

Note: Prior to use, thaw in a $37^{\circ} \mathrm{C}$ water bath and dilute to $100 \mathrm{ml}$ with versene solution (see Recipe 13). Do not heat trypsin at $37^{\circ} \mathrm{C}$ for $>20 \mathrm{~min}$, as auto-digestion of the enzyme will occur.

\section{Tryptose phosphate broth (TPB)}

Weigh out 29.5 g tryptose phosphate broth (TPB; Difco)

Dissolve in a total volume of $1 \mathrm{~L}$ tissue culture grade water

Autoclave TPB for $20 \mathrm{~min}$ in two separate 500 -ml volumes to sterilize

Do not leave in the autoclave for longer periods since this solution will caramelize

Cool and store up to 6 months at $4{ }^{\circ} \mathrm{C}$ 


\title{
13. Versene solution
}

\author{
$500 \mathrm{ml} 1 \times$ PBS-D (see Recipe 7 for $10 \times$ ) \\ $5 \mathrm{ml} 0.1 \mathrm{M}$ EDTA (see Recipe 14) \\ $1.5 \mathrm{ml}$ 0.5\% phenol red (see Recipe 9) \\ Adjust $\mathrm{pH}$ to 7.4 with $\mathrm{NaOH}$ \\ Filter sterilize (if sterile stock solutions were not used) \\ Store up to 6 months at room temperature
}

\section{0.1 M EDTA solution}

Use the disodium salt form $3.36 \mathrm{~g} / 100 \mathrm{ml}$

The $\mathrm{pH}$ will drop below 5.3 and solution will remain cloudy until its $\mathrm{pH}$ is adjusted to 7.0. Adjust the $\mathrm{pH}$ to 8.0 with $\mathrm{NaOH}$

Autoclave to sterilize

\section{M-PER Supplemented with $\mathbf{5 0} \mathbf{~ m M}$ dithiothreitol (DTT)}

a. First, make $1 \mathrm{ml}$ of a $1 \mathrm{M}$ stock solution of DTT by adding $154.25 \mathrm{mg}$ DTT (Sigma) to 1,000 $\mu \mathrm{l}$ mass spec grade water. Mix by vortexing.

b. Make $1 \mathrm{ml}$ of DTT-supplemented M-PER (Thermo Scientific) by adding $50 \mu \mathrm{l} 1 \mathrm{M}$ DTT to $950 \mu \mathrm{l}$ M-PER in order to have an excess of solution.

Notes:

i. You will need a minimum of $20 \mu \mathrm{l}$ of DTT-supplemented M-PER for every sample you process.

ii. Leftover $1 \mathrm{M}$ DTT stock can be stored at $-20^{\circ} \mathrm{C}$ for up to 30 days (it is best make $50-100 \mu$ l aliquots to prevent any freeze/thaw cycles).

\section{UA buffer (8 $\mathrm{M}$ urea, $100 \mathrm{mM}$ Tris-HCl pH 8.5) (10 ml)}

Note: You will need around $500 \mu \mathrm{l}$ of UA buffer per sample.

Add $4.8048 \mathrm{~g}$ urea (Thermo Scientific) to $6 \mathrm{ml}$ mass spec grade water and dissolve (the solution will become cold, so it may be necessary to heat the solution gently in a water bath to get the urea to dissolve completely). Add $1 \mathrm{ml} 1 \mathrm{M}$ Tris-HCl pH 8.5 and add mass spec grade water to $10 \mathrm{ml}$

\section{IAA solution ( $0.05 \mathrm{M}$ iodoacetamide in $\mathrm{UA}$ buffer $)(1 \mathrm{ml})$}
a. $\quad$ Add 9.248 mg IAA powder (I1149-25G) to 1,000 $\mu \mathrm{l}$ mass spec grade water and vortex
b. Keep powder and solution protected from light at all times
c. It is recommended to wrap the IAA solution tube in foil to keep out light
d. Recommended to keep solution on ice

\section{8. $100 \mathrm{mM}$ triethylammonium bicarbonate (TEAB) (3 ml)}

Add $300 \mu \mathrm{l} 1 \mathrm{M}$ TEAB (Sigma) to $2.7 \mathrm{ml}$ mass spec grade water and vortex

Recommended to keep solution on ice

19. Trypsin digestion solution (Trypsin/Lys-C prepared in $100 \mathrm{mM}$ TEAB to $10 \mu \mathrm{g} / \mathrm{ml}$ )

Add 2,000 $\mu \mathrm{l} 100 \mathrm{mM}$ TEAB to a single $20 \mu \mathrm{g}$ vial of Trypsin/Lys-C (Promega) for a final concentration of 10 $\mu \mathrm{g} / \mathrm{ml}$, and gently pipet-mix until completely dissolved. DO NOT VORTEX. Recommended to keep solution on ice

\section{0.5 M NaCl (5 ml)}

Note: this will be an excess of solution, but it is a more manageable to weigh out NaCl for this volume). Weigh out $146.1 \mathrm{mg} \mathrm{NaCl}$ (Sigma) and add mass spec grade water to $5 \mathrm{ml}$ Vortex until dissolved

\section{1. $10 \%$ trifluoroacetic acid}

Add $1 \mathrm{ml}$ of $100 \%$ trifluoroacetic acid (Thermo Scientific) to $9 \mathrm{ml}$ mass spec grade water and vortex 


\section{A Buffer (3\% acetonitrile/0.1\% formic acid)}

Add $1 \mathrm{ml}$ 100\% formic acid (Thermo Scientific) to $30 \mathrm{ml}$ 100\% acetonitrile, then add mass spec grade water to $1 \mathrm{~L}$

\section{B buffer (95\% acetonitrile/0.1\% formic acid)}

Add $1 \mathrm{ml} 100 \%$ formic acid to $950 \mathrm{ml} 100 \%$ acetonitrile, then add mass spec grade water to $1 \mathrm{~L}$

\section{Acknowledgments}

RH and DF were supported by the Clayton Foundation for Research, Carson City NV and the College of Agriculture and Natural Sciences, North Carolina State University. TG and GR were supported by the U.S. Army Combat Capabilities Development Command (CCDC) Chemical Biological Center through an internal basic research grant. The opinions presented here are those of the authors and are not the official policy of the U.S. Army, CCDC, or the U.S. Government. Information in this report is cleared for public release and distribution is unlimited. This protocol is adapted from the publication. Schuchman R, Kilianski A, Piper A, Vancini R, Ribeiro JMC, Sprague TR, Nasar F, Boyd G, Hernandez R, Glaros T. 2018. Comparative Characterization of the Sindbis Virus Proteome from Mammalian and Invertebrate Hosts Identifies nsP2 as a Component of the Virion and Sorting Nexin 5 as a Significant Host Factor for Alphavirus Replication. J Virol 92.

\section{Competing interests}

The Authors declare no competing interests.

\section{References}

Brown, D. T. (1986). Replication of Alphaviruses in Mosquito Cells. In: The Togaviridae and Flaviviridae. Schlesinger, S. and Schlesinger, M. J. (Eds). Plenum Press. New York and London. 171-207.

Chen, X. G., Jiang, X., Gu, J., Xu, M., Wu, Y., Deng, Y., Zhang, C., Bonizzoni, M., Dermauw, W., Vontas, J., Armbruster, P., Huang, X., Yang, Y., Zhang, H., He, W., Peng, H., Liu, Y., Wu, K., Chen, J., Lirakis, M., Topalis, P., Van Leeuwen, T., Hall, A. B., Jiang, X., Thorpe, C., Mueller, R. L., Sun, C., Waterhouse, R. M., Yan, G., Tu, Z. J., Fang, X. and James, A. A. (2015). Genome sequence of the Asian Tiger mosquito, Aedes albopictus, reveals insights into its biology, genetics, and evolution. Proc Natl Acad Sci U S A 112(44): E59075915.

Coombs, K. and Brown, D. T. (1987). Topological organization of Sindbis virus capsid protein in isolated nucleocapsids. Virus Res 7(2): 131-149.

Giraldo-Calderón, G. I., Emrich, S. J., MacCallum, R. M., Maslen, G., Dialynas, E., Topalis, P., Ho, N., Gesing, S., VectorBase, C., Madey, G., Collins, F. H. and Lawson, D. (2015). VectorBase: an updated bioinformatics resource for invertebrate vectors and other organisms related with human diseases. Nucleic Acids Res 43 (Database issue): D707-713.

Glaros, T. G., Blancett, C. D., Bell, T. M., Natesan, M. and Ulrich, R. G. (2015). Serum biomarkers of Burkholderia mallei infection elucidated by proteomic imaging of skin and lung abscesses. Clin Proteomics 12(1): 7.

Hernandez, R., Brown, D. T. and Paredes, A. (2014). Structural differences observed in arboviruses of the alphavirus and flavivirus genera. Adv Virol 2014: 259382.

Johnson, J. E. and Speir, J. A. (1997). Quasi-equivalent viruses: a paradigm for protein assemblies. $J$ Mol Biol 269(5): 665-675.

Kall, L., Canterbury, J. D., Weston, J., Noble, W. S. and MacCoss, M. J. (2007). Semi-supervised learning for 
peptide identification from shotgun proteomics datasets. Nat Methods 4(11): 923-925.

Karim, S., Singh, P. and Ribeiro, J. M. (2011). A deep insight into the sialotranscriptome of the gulf coast tick, Amblyomma maculatum. PLOS One 6: e28525.

Mi, H., Poudel, S., Muruganujan, A., Casagrande, J. T. and Thomas, P. D. (2016). PANTHER version 10: expanded protein families and functions, and analysis tools. Nucleic Acids Res 44(D1): D336-342.

Ribeiro, J. M., Topalis, P. and Louis, C. (2004). AnoXcel: an Anopheles gambiae protein database. Insect Mol Biol 13(5): 449-457.

Rumble, J. R. (2005). CRC Handbook of Chemistry and Physics. Internet Version 2005, CRC Press, Boca Raton, FL.

Strauss, J. H. and Strauss, E. G. (1994). The alphaviruses: gene expression, replication, and evolution. Microbiol Rev 58(3): 491-562.

Vancini, R., Wang, G., Ferreira, D., Hernandez, R. and Brown, D. T. (2013). Alphavirus genome delivery occurs directly at the plasma membrane in a time- and temperature-dependent process. Journal of Virology 87(8): 4352-4359.

Wilkins, M. (2009). Proteomics data mining. Expert Rev Proteomics 6(6): 599-603.

Wilkins, M. R., Pasquali, C., Appel, R. D., Ou, K., Golaz, O., Sanchez, J. C., Yan, J. X., Gooley, A. A., Hughes, G., Humphery-Smith, I., Williams, K. L. and Hochstrasser, D. F. (1996). From proteins to proteomes: large scale protein identification by two-dimensional electrophoresis and amino acid analysis. Biotechnology (N Y) 14(1): 61-65.

Wiśniewski, J. R., Zougman, A., Nagaraj, N. and Mann, M. (2009). Universal sample preparation method for proteome analysis. Nat Methods 6(5): 359-362.

Wray, W., Boulikas, T., Wray, V. P. and Hancock, R. (1981). Silver staining of proteins in polyacrylamide gels. Anal Biochem 118(1): 197-203. 